\title{
Short-term effects of wasp-venom immunotherapy on the expression of the receptor for interleukin-7 (IL-7) on peripheral blood CD4+ T cells
}

\author{
Krótkoterminowe efekty działania immunoterapii jadem osy \\ na ekspresję receptora dla interleukiny 7 (IL-7) na komórkach T CD4+ \\ krwi obwodowej
}

\author{
Kamil K. Grubczak' ${ }^{1}$ Andrzej Eljaszewicz' ${ }^{1}$ Maria M. Tomasiak-Łozowska², Maciej Klimek², \\ Marcin Czaban², Aleksandra Starosz , Anna Bodzenta-Lukaszyk², Marcin Moniuszko ${ }^{1,2}$ \\ 'Department of Regenerative Medicine and Immune Regulation, Medical University of Bialystok, Bialystok, Poland \\ ${ }^{2}$ Department of Allergology and Internal Medicine, Medical University of Bialystok, Bialystok, Poland
}

\section{ABSTRACT}

Introduction: Induction of allergen tolerance through venom immunotherapy (VIT) remains the most effective therapeutic tool in the treatment of patients allergic to hymenoptera venom. To date, majority of beneficial effects of VIT (and specific immunotherapy in general) have been associated with the alteration of phenotype and function of CD4+ T cells. Homeostasis and survival of CD4+ T cells is strictly related to signaling mediated by interleukin-7 (IL-7) and its receptor, IL-7R (CD127). To date, however, there are no data on the effects of hymenoptera venom immunotherapy on IL-7 nor IL-7R.

Aim: Here, we evaluated short-term effects of wasp venom SIT on the expression of IL-7R on peripheral blood CD4+ T cells in wasp venom-sensitive patients within first 3 months of VIT.

Material and methods: Peripheral blood was collected from wasp venom-sensitive patients in the course of ultra-rush immune therapy using Venomenhal Wespe (HAL Allergy). Assessment of IL-7 receptor within CD4+ lymphocytes was performed using immunostaining with fluorochrome-labeled monoclonal antibodies and flow cytometric analysis.

Results: Although we found a trend to decreased expression of IL-7 receptor on CD4+ T cells within first $24 \mathrm{~h}$ of immunotherapy, however, in total, we did not demonstrate significant differences in frequencies of IL-7R-positive CD4+ T cells.

Conclusions: Acquired results suggest that wasp venom SIT does not seem to affect frequencies of CD4+CD127+ T cells at early stages of therapy. However, no data on effects of VIT on T cell phenotype in long-term observation justify need for further studies on hymenoptera VIT effects on IL-7/IL-7R axis in context of allergen tolerance induction.

\section{KEY WORDS}

IL-7R (CD127), CD4+ T cells, wasp venom allergy, specific immunotherapy. 


\section{STRESZCZENIE}

Wprowadzenie: Indukcja tolerancji na alergen z użyciem immunoterapii jadem (VIT) jest najbardziej skutecznym narzędziem w leczeniu pacjentów z alergią na jad błonkoskrzydłych. Dotychczas większość korzystnych efektów VIT (w tym swoistej immunoterapii ogólnie) była wiązana ze zmianami w fenotypie i funkcji komórek T CD4+. Homeostaza i przeżycie komórek T CD4+ ściśle wiążą się z sygnałami przekazywanymi przez interleukinę 7 (IL-7) i jej receptor - IL-7R (CD127). Jednak obecnie nie ma danych dotyczących wpływu immunoterapii jadem błonkoskrzydłych zarówno na IL-7, jak i IL-7R.

Cel: Ocena krótkoterminowych efektów SIT jadem osy dotyczących ekspresji IL-7R na komórkach T CD4+ krwi obwodowej pacjentów uczulonych na jad osy w pierwszych 3 miesiącach VIT.

Materiał i metody: Krew obwodowa została pobrana od pacjentów uczulonych na jad osy w przebiegu terapii immunologicznej w schemacie ultra-rush z wykorzystaniem Venomenhal Wespe (HAL Allergy). Ocenę receptora IL-7 w obrębie limfocytów CD4+ wykonano z użyciem barwienia immunologicznego przeciwciałami wyznakowanymi fluorochromami i analizy cytometrii przepływowej.

Wyniki: Pomimo tendencji do zmniejszonej ekspresji receptora IL-7 na komórkach T CD4+ po pierwszych 24 godzinach immunoterapii, ostatecznie nie stwierdzono istotnych różnic w odsetkach IL-7Rdodatnich komórek T CD4+.

Wnioski: Uzyskane wyniki sugerują, że SIT jadem osy nie wpływa na odsetki komórek T CD4+CD127+ na wczesnym etapie leczenia. Jednak brak danych na temat oddziaływania VIT na fenotyp limfocytów T w długoterminowej obserwacji uzasadnia potrzebę dalszych badań nad wpływem VIT błonkoskrzydłych na oś IL-7/IL-7R w kontekście indukowania tolerancji na alergeny.

\section{SŁOWA KLUCZOWE}

IL-7R (CD127), komórki T CD4+, alergia na jad osy, immunoterapia swoista.

\section{ADDRESS FOR CORRESPONDENCE}

Dr. Kamil K. Grubczak, Department of Regenerative Medicine and Immune Regulation, Medical University of Bialystok, ul. Waszyngtona 13, 15-269 Bialystok, Poland, e-mail: kamil.grubczak@gmail.com

\section{INTRODUCTION}

Venom immunotherapy (VIT) remains the most effective tool in causative treatment of systemic allergic reactions to hymenoptera venom [1]. In general, the effects of allergen-specific immune therapy (SIT) are based on the induction of tolerance to specific allergens in sensitized patients [2]. There is a large body of evidence indicating that tolerance to allergens achieved in the course of SIT can be strongly related with modulation of activities of regulatory T cells [3]. In fact, an increased expansion of $\mathrm{T}$ cells with immunosuppressive potential was observed in the course of VIT [4]. Many of the long-term immune effects of SIT have traditionally been linked to modulation of $\mathrm{CD} 4+\mathrm{T}$ cells, mainly those with a regulatory phenotype characterized by the high expression of CD25 and/or FoxP3 [3]. Recently, VIT has been shown to upregulate proliferation of regulatory $\mathrm{T}$ cells (Treg) delineated by the CD4+CD127(IL-7R)-CD25(IL-2R)+ phenotype and the expression of Foxp3 [4]. However, much less is known about complexity of mechanisms associated with allergen-specific immunotherapy and that justifies importance of continuous studies [5]. IL-7/IL-7R(CD127) axis is critical for all $\mathrm{T}$ cells' homeostasis [6], however, more recent data additionally underline a significant influence of IL-7 on allergen-induced memory CD4+ T cells [7]. Moreover, the chronic activation status of immune cells in the course of viral infection or asthma was associated with a significant decrease in IL-7R expression on T cells, the process being efficiently restored by glucocorticoid treatment [8]. However, despite numerous studies on allergy immunotherapy, there are no data on the effects of this kind of treatment on IL-7R levels in CD4+ T cells in wasp venom allergic patients.

\section{AIM}

Here, we intended to analyze whether ultra-rush wasp venom specific immunotherapy might influence IL-7R expression on $\mathrm{CD} 4+\mathrm{T}$ cells in allergic subjects. 


\section{MATERIAL AND METHODS}

\section{PATIENTS}

This pilot study was conducted on ten wasp venom-sensitive patients subjected to ultra-rush immune therapy using Venomenhal Wespe (HAL Allergy). EDTA-anticoagulated peripheral blood was collected from patients at three time points: up to $1 \mathrm{~h}$ prior to the first injection, after $24 \mathrm{~h}$, and at day 120 .

\section{FLOW CYTOMETRY}

Immunostaining with fluorochrome-labeled monoclonal antibodies was performed on $150 \mu$ l of blood samples, using $5 \mu \mathrm{l}$ of each selected antibody: anti-CD4 FITC and anti-CD127 (IL-7R) PE (BD Bioscience). 25-minute incubation was followed by erythrocyte lysis with the use of FACS Lysing Solution (BD Bioscience), and subsequent double washing of cells in phosphate-buffered saline (PBS, Biomed Lublin). Flow cytometric data acquisition was conducted on FACS Calibur flow cytometer (Becton-Dickinson, San Jose, CA, USA) and analyses were performed with the use of FlowJo software (Three Star Inc.) XX was used to perform analysis of the collected flow cytometric data. Proper gating of CD4+CD127+ cells was based on unstained and fluorescence minus one (FMO) controls (Figure 1).

\section{STATISTICAL ANALYSIS}

Wilcoxon matched pairs test (due to non-normal distribution) was used for statistical analysis of the data. Obtained data were presented as frequency and mean fluorescence intensity (MFI) of CD127 marker within CD4+ T cells. Statistical analyses were performed using GraphPad Prism 5 software (GraphPad Software Inc., San Diego, CA, USA).

\section{RESULTS}

In general, we did not reveal any significant changes in IL-7R frequencies within CD4+ T cells in the course of first 3 months of wasp-venom immunotherapy (Figures $2 \mathrm{~A}$, C; Table 1). However, with regard to the MFI of IL-7R, we found an insignificant decrease in the expression of IL-7R on CD4+ T cells at day $1(\mathrm{MFI}=72.20)$ as compared to day $0(\mathrm{MFI}=96.40)(p=0.0547)$. In addition, at day 120 we observed a return of IL-7R MFI to baseline levels $(\mathrm{MFI}=106.5)($ Figures $2 \mathrm{~B}, \mathrm{C}$; Table 1$)$.

\section{DISCUSSION}

Here, we intended to investigate effects of wasp venom ultra-rush desensitization therapy on the expression of IL-7R (CD127) in CD4+ T cells. First, we did not find any significant changes in frequency of CD4+CD127+ $\mathrm{T}$ cells at any of the time points during allergen-specific immune therapy. Interestingly however, non-significant decline in mean fluorescence intensity of CD127 expression on CD4+ cells was observed. Noteworthy, similar results were observed in asthmatic patients, where shortly (6-and 24-hours) after intrabronchial allergen provocation with HDM (house dust mite), a significant decrease in IL-7R was observed in CD4+ T-cells [8]. Noteworthy, allergen challenge in patients allergic to dust mite is also associated with a decline in frequency of CD4+CD25+CD127- regulatory $\mathrm{T}$ cells [9]. Considering a well-known essential role of IL-7R in the $\mathrm{T}$ cell survival and homeostasis [10-12], complementary studies will be necessary to investigate changes of $\mathrm{T}$ cells function in response to desensitization therapies. It was shown previously that in certain conditions IL-7R levels positively correlate with the frequency of regulatory T cells [13]. Additionally, a low expression of IL-7R is one of the surface markers that enable to distinguish $\mathrm{T}$ cells with a regulatory phenotype [14,

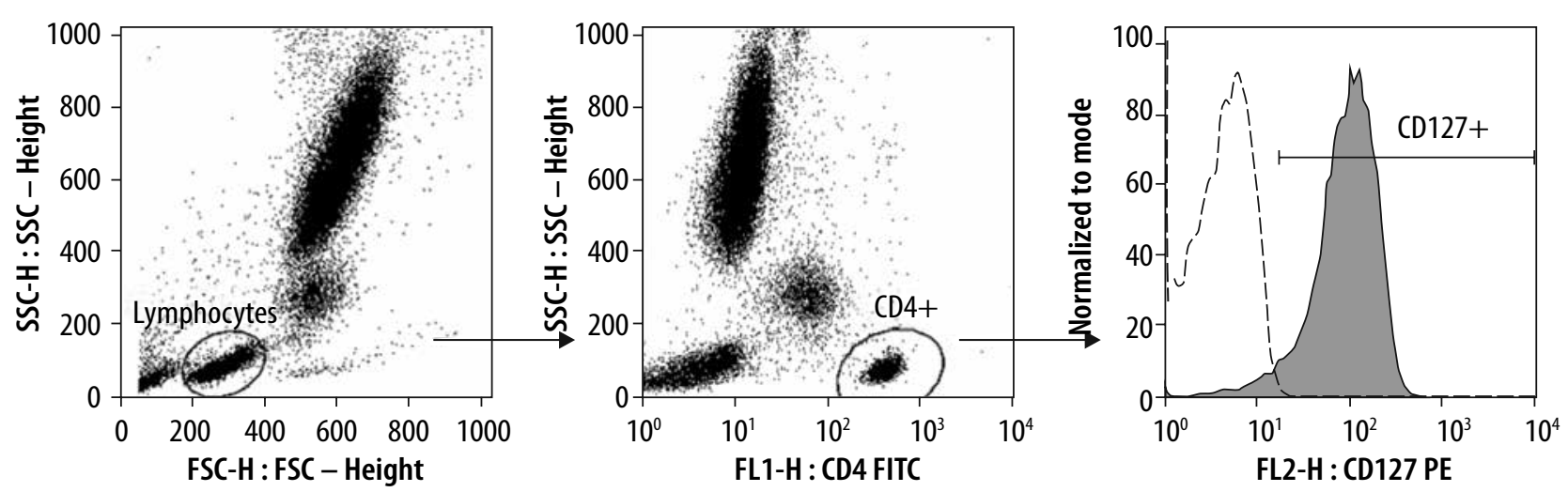

FIGURE 1. Gating strategy used to delineate CD127 (IL-7R) within CD4+ lymphocytes, based on forward/side scatter properties (FSC/SSC), expression of CD4 (T cells marker), and CD127 (IL-7R). The histogram with dashed lines represents fluorescence minus one (FM0) control 
A

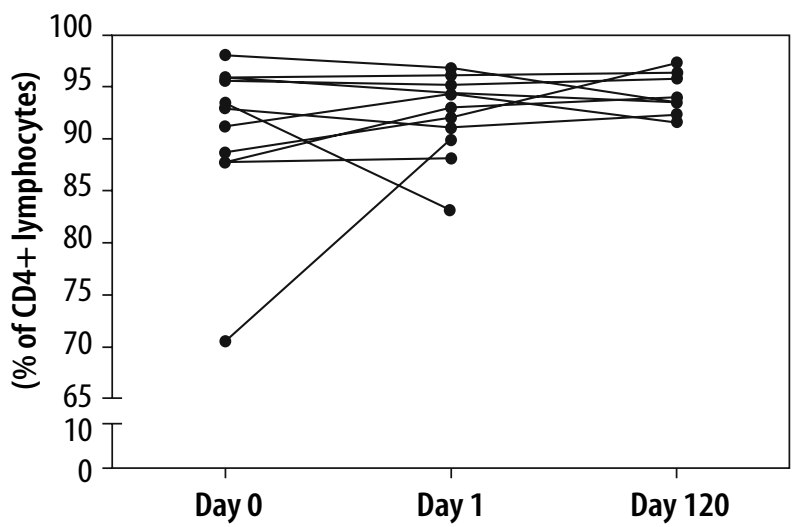

B

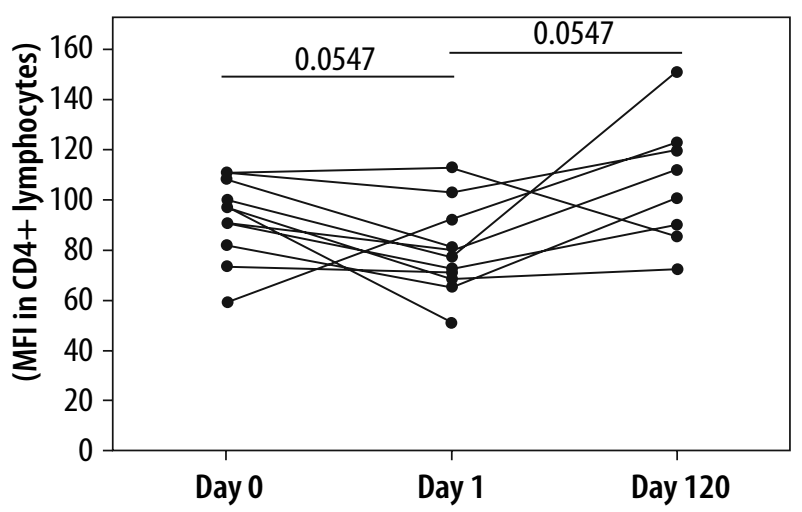

C

Day 0

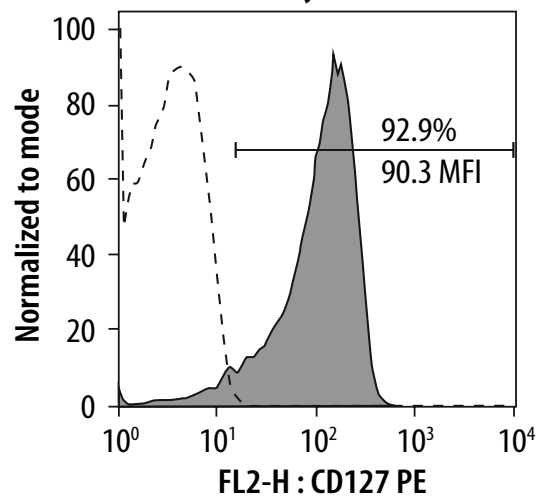

Day 1
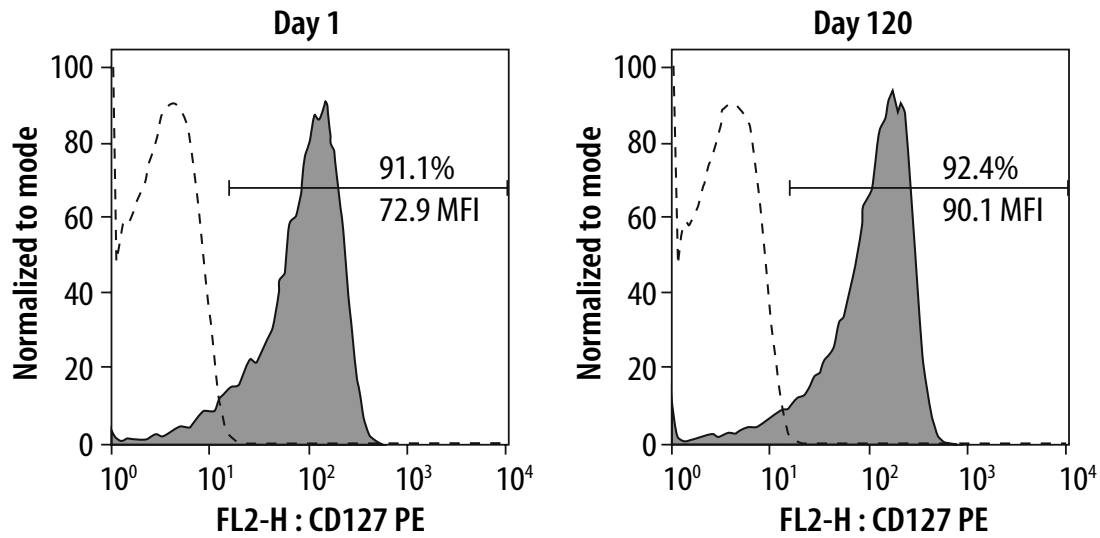

FIGURE 2. Specific immune therapy effects on frequency of CD127+ (IL-7R+) within CD4+ T cells (A), and mean fluorescence intensity (MFI) of CD127 in CD4+ cells (B). Corresponding sample histograms are included in the lower row (C)

TABLE 1. Tabular results of ultra-rush immune therapy effects on frequency and mean fluorescence intensity (MFI) of IL-7R (CD127) within CD4+ lymphocytes in patients allergic to wasp venom. Data presented as median values with $25^{\text {th }}$ and $75^{\text {th }}$ in the brackets respectively

\begin{tabular}{|l|c|c|c|}
\hline \multirow{2}{*}{ Parameter } & \multicolumn{3}{|c|}{ Ultra-rush immune therapy time points } \\
\cline { 2 - 4 } & Day 0 & Day 1 & Day 120 \\
\hline IL-7R+ (CD127+) & 92.90 & 93.10 & 93.85 \\
(\% of CD4+ lymphocytes) & $(87.90 ; 95.90)$ & $(90.00 ; 95.30)$ & $(92.68 ; 96.35)$ \\
\hline IL-7R (CD127) & 96.40 & 72.20 & 106.5 \\
(MFl in (D4+ lymphocytes) & $(82.20 ; 108.0)$ & $(68.60 ; 92.30)$ & $(86.95 ; 122.3)$ \\
\hline
\end{tabular}

15]. These results seem to be in concert with previous studies indicating the effect of venom immunotherapy (VIT) on allergen-specific regulatory $\mathrm{T}$ cells generation, and subsequent restoration of normal tolerance [16]. Further research might reveal whether IL-7R expression is followed by regulatory $\mathrm{T}$ cells distribution and how these factors influence the outcome of wasp venom ultra-rush desensitization therapy. Another crucial argument justifying the need for more comprehensive studies on IL-7R is the fact some changes at later stages of the immunotherapy [17], therefore prolonged monitoring will be required.

\section{CONCLUSIONS}

Our findings suggest that wasp venom SIT at early stages of therapy does not seem to affect frequencies of CD4+CD127+ T cells. However, late effects of VIT on T cell phenotype will have to be analyzed. Therefore, further studies are warranted to establish the long-term effects of hymenoptera VIT on IL-7/IL-7R axis and its role in the induction of allergen tolerance.

\section{CONFLICT OF INTEREST}

The authors declare no conflict of interest. 


\section{REFERENCES}

1. Dhami S, Zaman H, Varga EM, et al. Allergen immunotherapy for insect venom allergy: a systematic review and meta-analysis. Allergy 2017; 72: 342-65.

2. Akdis CA, Akdis M. Mechanisms of allergen-specific immunotherapy and immune tolerance to allergens. World Allergy Organ J 2015; 8: 17.

3. Fujita H, Soyka MB, Akdis M, Akdis CA. Mechanisms of allergen-specific immunotherapy. Clin Transl Allergy 2012; 2 : 2 .

4. Caramalho I, Melo A, Pedro E, et al. Bee venom enhances the differentiation of human regulatory T cells. Allergy 2015; 70: 1340-5.

5. Jutel M, Van de Veen W, Agache I, et al. Mechanisms of allergen-specific immunotherapy and novel ways for vaccine development. Allergol Int 2013; 62: 425-33.

6. Fry TJ, Mackall CL. The many faces of IL-7: from lymphopoiesis to peripheral T cell maintenance. J Immunol 2005; 174: 6571-6.

7. Yeon SM, Halim L, Chandele A, et al. IL-7 plays a critical role for the homeostasis of allergen-specific memory CD4 T cells in the lung and airways. Sci Rep 2017; 7: 11155.

8. Moniuszko M, Lipinska D, Jeznach M, et al. Glucocorticoids upregulate decreased IL-7 receptor expression in asthmatic patients and simian immunodeficiency virus-infected non-human primates. J Biol Regul Homeost Agents 2013; 27: 427-42.

9. Moniuszko M, Kowal K, Zukowski S, et al. Frequencies of circulating CD4+CD25+CD127low cells in atopics are altered by bronchial allergen challenge. Eur J Clin Invest 2008; 38: 201-4.

10. Jacobs SR, Michalek RD, Rathmell JC. IL-7 is essential for homeostatic control of T cell metabolism in vivo. J Immunol 2010; 184: 3461-9.

11. Boyman O, Purton JF, Surh CD, Sprent J. Cytokines and T-cell homeostasis. Curr Opin Immunol 2007; 19: 320-6.

12. Moniuszko M, Edghill-Smith Y, Venzon D, et al. Decreased number of CD4(+) and CD8(+) T cells that express the interleukin-7 receptor in blood and tissues of SIV-infected macaques. Virology 2006; 356: 188-97.

13. Bossowski A, Moniuszko M, Dąbrowska M, et al. Lower proportions of CD4+CD25(high) and CD4+FoxP3, but not CD4+CD25+CD127(low) FoxP3(+)T cell levels in children with autoimmune thyroid diseases. Autoimmunity 2013; 46: 222-30.

14. Miyara M, Sakaguchi S. Human FoxP3(+)CD4(+) regulatory T cells: their knowns and unknowns. Immunol Cell Biol 2011; 89: 346-51.

15. Kaczorowski M, Jutel M. Human T regulatory cells: on the way to cognition. Arch Immunol Ther Exp 2013; 61: 229-36.

16. Ozdemir C, Kucuksezer UC, Akdis M, Akdis CA. Mechanisms of immunotherapy to wasp and bee venom. Clin Exp Allergy 2011; 41: 1226-34.

17. Pereira-Santos MC, Baptista AP, Melo A, et al. Expansion of circulating Foxp3+)D25bright CD4+ T cells during specific venom immunotherapy. Clin Exp Allergy 2008; 38: 291-7. 